\title{
PENGARUH STRATEGI PROMOSI, CITRA MERK DAN KUALITAS PRODUK TERHADAP KEPUTUSAN PEMBELIAN DI GUYUB RUKUN MART BANJARMANGU, BANJARNEGARA
}

\author{
Ratna Suryani ${ }^{1}$; Gustio Bayu Adhitama ${ }^{2}$ \\ STIE Tamansiswa Banjarnegara Jl. Mayjend Panjaitan No.29 Banjarnegara \\ Email : ratnasuryani@stietsbanjarnegara.ac.id ${ }^{1}$; gustiobayu1708@gmail.com²
}

\begin{abstract}
The problems experienced by Guyub Rukun Mart is the lack of a promotional strategy carried out and the lack of promotion carried out by Guyub Rukun Mart, so that the general public still doesn't know about it. This is because the Guyub Rukun Mart is not an economist, plus the Guyub Rukun Mart brand image. Marts that are not well known to the wider community and the quality of the products sold do not all have the quality that is in accordance with the wishes of the community. This study aims to determine the effect of promotional strategies, brand image and product quality on purchasing decisions. In this study, researchers used quantitative methods. The data source used is primary data. The sampling technique used random sampling technique. The data was collected by using a questionnaire distributed directly to buyers as many as 98 respondents. Data analysis in this study used multiple linear regression analysis with SPSS version 24. The results of this study indicate that promotional strategies and product quality affect purchasing decisions, while brand image does not affect purchasing decisions but jointly promotional strategies, brand image and product quality affect purchasing decisions.
\end{abstract}

Keywords: Promotion Strategy, Brand Image, Product Quality, Purchase Decision

\section{PENDAHULUAN}

\section{Latar Belakang}

Keputusan pembelian adalah suatu konsep dalam perilaku pembelian dimana konsumen memutuskan untuk melakukan sesuatu dan dalam hal ini melakukan pembelian ataupun memanfaatkan produk atau jasa tertentu (Balawera, 2013). Peneliti menggunakan

variabel keputusan pembelian ini karena studi tentang keputusan pembelian layak untuk diteliti mengingat banyaknya produk yang beredar mengakibatkan perlunya berbagi pertimbangan bagi masyarakat dalam melakukan keputusan pembelian. Keputusan pembelian akan 
terjadi apabila produk tersebut sesuai dengan apa yang diinginkan dan dibutuhkan oleh konsumen.

Strategi promosi merupakan kegiatan penting dalam perusahaan yang ditujukan untuk memenuhi target penjualan melalui suatu produk yang diharapkan dapat memberikan manfaat untuk konsumen. Sebagian besar kegagalan usaha yang terjadi disebabkan oleh gagalnya perusahaan mendefinisikan pasar yang dituju dan bagaimana potensinya dan banyaknya jumlah konsumen membuat sebuah perusahaan atau organisasi tidak dapat memasuki semua segmen pasar. Perusahaan harus dapat mengidentifikasi segmen pasar yang dapat dilayani paling efektif, yaitu dengan cara menyusun strategi promosi yang baik (Keller, 2016).

Saat terjadinya keputusan pembelian biasanya hal yang pertama yang dipertimbangkan konsumen untuk membeli suatu produk adalah citra merk. Citra merk dalam sebuah produk memiliki peran yang cukup penting bagi konsumen dalam melakukan keputusan pembelian. Hal tersebut merupakan salah satu pertimbangan utama yang akan dilakukan oleh konsumen dalam melakukan keputusan pembelian. Seperti studi yang telah dilakukan oleh Lay Yee et al (2013) yang menunjukan bahwa ada hubungan yang signifikan antara merk dengan keputusan pembelian. Produk yang memiliki merk dan berkualitas tinggi akan lebih menarik konsumen untuk memakai produk tersebut (Park et al, 2012).
Kualitas produk adalah kemampuan sebuah produk dalam memperagakan fungsinya, hal ini tersebut termasuk keseluruhan durabilitas, reliabilitas, ketepatan, kemudahan pengoprasian dan reparasi produk juga atribut produk lainya. Kualitas produk dianggap sangat penting bagi organisasi karena meningkatkan reputasi perusahaan, perusahaan yang telah menghasilkan produk atau jasa yang berkualitas akan mendapat predikat sebagai organisasi yang mengutamakan kualitas (Kotler, 2012).

Strategi promosi, citra merk, dan kualitas produk memberikan manfaat yang sangat besar bagi kelancaran proses kegiatan bisnis, salah satunya untuk mendorong keputusan pembelian terhadap suatu produk yang nantinya akan di pasarkan oleh perusahaan, strategi promosi yang tepat akan membantu kita untuk mencapai target penjualan, citra merk dan kualitas produk yang baik akan mendorong seorang konsumen untuk melakukan keputusan pembelian (Tjipjono, 2012).

Permasalahan yang dialami oleh GR. Mart adalah kurangnya strategi promosi yang dilakukan dan masih kurangnya promosi yang dilakukan oleh GR.mart ini sehingga masyarakat pada umumnya masih banyak yang belum mengetahuinya. Hal ini dikarenakan pengurus GR. Mart bukan dari ahli ekonomi, ditambah lagi dengan citra merk GR. Mart yang belum dikenal oleh masyarakat luas dan kualitas produk yang dijual tidak semuanya mempunyai kualitas yang sesuai dengan keinginan 
masyarakat. Pembeli atau pelanggan di GR.Mart mengalami fluktuatif di tahun 2019 dengan melihat tabel dibawah ini,

Tabel 1.1 Data Pembeli GR. Mart Tahun 2019

\begin{tabular}{|c|c|}
\hline Bulan & Pembeli \\
\hline Januari & 397 \\
\hline Februari & 410 \\
\hline Maret & 415 \\
\hline April & 395 \\
\hline Mei & 402 \\
\hline Juni & 372 \\
\hline Juli & 380 \\
\hline Agustus & 368 \\
\hline September & 401 \\
\hline Oktober & 373 \\
\hline November & 392 \\
\hline Desember & 387 \\
\hline Total & $\mathbf{4 . 6 9 2}$ \\
\hline
\end{tabular}

\section{Sumber : GR Mart, 2019}

Hasil penelitian yang dilakukan oleh Aprianto (2016) menunjukan bahwa strategi promosi berpengaruh positif terhadap keputusan pembelian. Artinya semakin tepat strategi promosi yang digunakan, maka semakin tinggi keputusan pembelian yang akan dilakukan oleh konsumen. Namun hasil penelitian ini berbeda dengan penelitian yang dilakukan oleh Nugraheni (2013) bahwa strategi promosi tidak terdapat pengaruh terhadap keputusan pembelian.

Hasil penelitian yang dilakukan oleh Sulistyawati (2010) menunjukan bahwa citra merk berpengaruh terhadap keputusan pembelian. Artinya semakin bagus citra merk yang dimiliki, maka semakin tinggi keputusan pembelian yang akan dilakukan oleh konsumen. Namun hasil penelitian ini berbeda dengan penelitian yang dilakukan oleh Sari, Mandey, dan Soegito (2014) bahwa citra merk tidak terdapat pengaruh terhadap keputusan pembelian.

Hasil penelitian yang dilakukan oleh Sugiono (2013) menunjukan bahwa Kualitas produk berpengaruh terhadap keputusan pembelian. Artinya semakin baik kualitas produk yang diberikan, maka semakin tinggi keputusan pembelian yang akan dilakukan oleh konsumen. Namun hasil penelitian ini berbeda dengan penelitian yang dilakukan oleh Rawung, Oroh, dan Sumaraw (2015) bahwa kualitas produk tidak terdapat pengaruh terhadap keputusan pembelian.

Dari latar belakang di atas peneliti tertarik untuk melakukan penelitian dengan judul "Pengaruh Strategi Promosi, Citra Merk, dan Kualitas Produk Terhadap Keputusan Pembelian di GR. Mart Banjarmangu, Banjarnegara.

\section{Rumusan Masalah}

Berdasarkan penjabaran latar belakang masalah di atas dapat 
diambil rumusan masalah dapat
diambil rumusan masalah sebagai
berikut:

1. Apakah strategi promosi

berpengaruh terhadap keputusan pembelian?

2. Apakah citra merk berpengaruh terhadap keputusan pembelian?

3. Apakah kualitas produk

berpengaruh terhadap keputusan pembelian?

4. Apakah strategi promosi, citra merk, dan kualitas produk secara simultan berpengaruh terhadap keputusan pembelian?

\section{METODE PENELITIAN}

\section{Lokasi Penelitian}

Penelitian ini dilakukan di Guyub Rukun Mart Banjarmangu, Banjarnegara.

\section{Jenis Penelitian}

Penelitian ini menggunakan data kuantitatif.

\section{Variabel Penelitian}

1. Strategi promosi(X1)

2. Citra merek (X2)

3. Kualitas produk (X3)

4. Keputusan Pembelian (Y)

\section{Definisi Konsep Dan Operasional Variabel}

1. Strategi Promosi

Definisi Konsep : Strategi promosi merupakan kegiatan penting dalam perusahaan yang ditujukan untuk memenuhi target penjualan melalui suatu produk yang diharapkan dapat memberikan manfaat untuk konsumen (Keller, 2016).

Definisi Operasional : Strategi promosi merupakan rencana yang dibuat untuk meningkatkan penjualan.

2. Citra Merk

Definisi Konsep : Citra merk adalah bagaimana pelanggan dan orang lain memandang suatu merk (Aaker, 2011).

Definisi Operasional : Citra merk merupakan penilaian konsumen terhafap merk dalam sebuah pasar.

3. Kualitas Produk

Definisi Konsep : Kualitas produk adalah kemampuan sebuah produk dalam memperagakan fungsinya (Kotler, 2012)

Definisi Operasional : Kualitas produk adalah kekuatan suatu produk yang berkaitan dengan masa pakai.

4. Keputusan Pembelian

Definisi Konsep : Keputusan pembelian adalah suatu keputusan konsumen yang dipengaruhi oleh ekonomi keuangan, tekhnologi, politik, budaya, produk, harga, lkasi, promosi, physical evidence, people dan process (Alma, 2013).

Definisi Operasional : Keputusan pembelian merupakan suatu ptoses pemilahan salah satu dari beberapa alternatif yang ada.

\section{Populasi, Sampel, Dan teknik Sampel}

1. Populasi

Populasi adalah wilayah generalisasi yang terdiri atas obyek atau subyek yang mempunyai kualitas dan karakteristik tertentu yang ditetapkan oleh peneliti untuk dipelajari. Jadi populasi bukan hanya orang, tetapi juga obyek dan bendabenda alam yang lain (Sugiyono, 2012). 
Berdasarkan pengertian tersebut maka populasi dalam penelitian ini adalah konsumen yang melakukan pembelian di GR. Mart, selama tahun 2019 sejumlah 4.692 orang.

2. Sampel

Sampel adalah sebagian dari jumlah dan karakteristik yang dimiliki populasi tersebut (Sugiono, 2010). Jumlah populasi yang akan diteliti adalah sejumlah 4.692 orang dengan menggunakan rumus Slovin untuk mencari jumlah sampel penelitian kesalahan yang dikehendaki adalah 10\%, maka jumlah sampel yang digunakan adalah:

$$
\begin{aligned}
\mathrm{n} & =\frac{\mathrm{N}}{1+\mathrm{Ne}^{2}} \\
& =\frac{4692}{1+\left(4.692 \times(10 \%)^{2}\right.} \\
& =\frac{4692}{1+(4.692 \times 0,1)^{2}} \\
& =98(\text { Sampel })
\end{aligned}
$$

Keterangan :

$\mathrm{n}$ = sampel

$\mathrm{N}=$ populasi

$\mathrm{e}=$ Nilai persentase kesalahan $=0,01$

Responden dalam penelitian ini adalah sejumlah 98 orang yang semua sampel adalah konsumen Guyub Rukun Mart Banjarmangu Kabupaten Banjarnegara.

3. Teknik pengambilan sampel

Teknik sampel adalah bagian dari metodologi statistika yang berhubungan dengan pengambilan sebagian dari populasi atau teknik yang dilakukan untuk menentukan sampel (Sugiyono, 2010). Teknik pengambilan sampel yang digunakan adalah random sampling.
Random sampling adalah teknik penentuan sampel dimana setiap anggota populasi mempunyai peluang yang sama untuk dipilih menjadi sampel. Dengan kata lain semua anggota tunggal dari populasi memiliki peluang.

\section{Teknik Analisis Data}

Adapun Teknik analisis data yang digunakan dalam penelitian ini adalah :

a. Uji Asumsi Klasik, terdiri dari :

1. Uji Normalitas

Uji normalitas digunakan untuk memperlihatkan bahwa sampel diambil dari populasi yang berdistribusi normal. Untuk uji normalitas penelitian ini menggunakan teknik uji kolmogorov-smirnov yaitu dengan membandingkan distribusi data yang akan diuji normalitasnya dengan distribusi normal baku. Distribusi normal baku adalah data yang telah ditranformasikan ke dalam bentuk Z-Score dan diasumsikan normal dengan pedoman sebagai berikut :

a. Hipotesis diterima apabila $p$ value $(\mathrm{sig})>\mathrm{a}=0,10$

b. Hipotesis ditolak apabila $p$ value $(\mathrm{Sig})<\mathrm{a}=0,10$

2. Uji Heteroskedastisitas

Uji heteroskedastisitas bertujuan untuk menguji apakah dalam model regresi terjadi ketidaksamaan variabel. Untuk menguji heteroskedastisitas digunakan metode scatterplot. Metode scatterplot adalah suatu metode penentuan persamaan suatu garis dengan memplot data dalam suatu grafik. Heteroskedastisitas terjadi dalam 
regresi apabila varian error (ei) tidak konstan untuk beberapa nilai (x).Pendeteksian konstan tidaknya varian error dilakukan dengan menggambar grafik antara (y) dengan residu.Apabila garis yang membatasi sebaran titik-titik relatif pararel maka varian error dikatakan konstan.

3. Uji Multikolonieritas

Uji multikoloniaritas bertujuan untuk mennguji apakah dalam suatu model regresi ditemukan adanya korelasi antar variabel independent. Uji multikolinearitas dilakukan dengan uji regresi, dengan nilai 50 patokan VIF (Variance Inflation Factor) dan koefisien korelasi antar variabel bebas. Kriteria yang digunakan adalah sebagai berikut:

a. Jika nilai VIF di sekitar angka 1 atau memiliki toleransi mendekati 1, maka dikatakan tidak terdapat masalah multikolinearitas.

b. Jika koefisien antar variabel bebas kurang dari 0.10, maka tidak terdapat masalah multikolinearitas.

b. Uji Hipotesis, terdiriari :

1. Uji Signifikan Parsial (Uji T)

Uji parsial adalah uji statistik secara individu untuk mengetahui pengaruh masing-masing variabel bebas terhadap variabel terikat. Uji $\mathrm{T}$ digunakan untuk menguji pengaruh variabel bebas terhadap variabel terikat secara parsial (sendiri-sendiri). Pengujian ini dilakukan dengan cara membandingkan nilai pada $\mathrm{T}$ tabel. Apabila $\mathrm{T}$ tabel $>\mathrm{T}$ hitung dengan signifikan dibawah 0,10 (10\%). Maka secara parsial variabel bebas berpengaruh positif terhadap variabel terikat, begitu juga sebaliknya (Sugiyono, 2011). 2. Uji Signifikansi Simultan (Uji F)

Uji F digunakan untu mengetahui ada tidaknya pengaruh secara bersama-sama variabel bebas terhadap variabel terikat secara bersamaan, yaitu dengan membandingkan antara $\mathrm{F}$ hitung dengan $\mathrm{F}$ tabel pada tingkat kepercayaan $10 \%$ apabila $\mathrm{F}$ hitung > F tabel maka semua variabel bebas berpengaruh positif secara bersamaan terhadap variabel terikat (Sugiyono, 2011).

3. Uji Determinasi $\left(\mathrm{R}^{2}\right)$

Koefisien determinasi $\left(\mathrm{R}^{2}\right)$ digunakan untuk mengukur seberapa jauh kemampuan model dalam menerangkan variasi variabel independen. Koefisien determinasi ini digunakan karena dapat menjelaskan kebaikan dari model regresi dalam memprediksi variabel dependen. Nilai koefisien adalah antara nol dan satu (Ghozali, 2013).

\section{HASIL DAN PEMBAHASAN}

\section{A. Hasil Uji Asumsi Klasik}

\section{Uji Normalitas}

One-Sample Kolmogorov-Smirnov Test

Standardized

Residual

\begin{tabular}{|c|c|c|}
\hline $\mathrm{N}$ & & 98 \\
\hline \multirow{4}{*}{$\begin{array}{l}\text { Normal } \\
\text { Parameters } \\
\text { b }\end{array}$} & Mean & 0000000 \\
\hline & $\begin{array}{l}\text { Std. } \\
\text { Deviation }\end{array}$ & ,98441463 \\
\hline & Absolute & ,076 \\
\hline & Positive & ,076 \\
\hline
\end{tabular}




\begin{tabular}{lc}
\hline Most $\quad$ Negative &,- 063 \\
Extreme & \\
Differences & \\
\hline Test Statistic &, 076 \\
\hline & \\
\hline Asymp. Sig. (2-tailed) &, $182^{\mathrm{c}}$ \\
\hline
\end{tabular}

a. Test distribution is Normal.

b. Calculated from data.

c. Lilliefors Significance Correction.

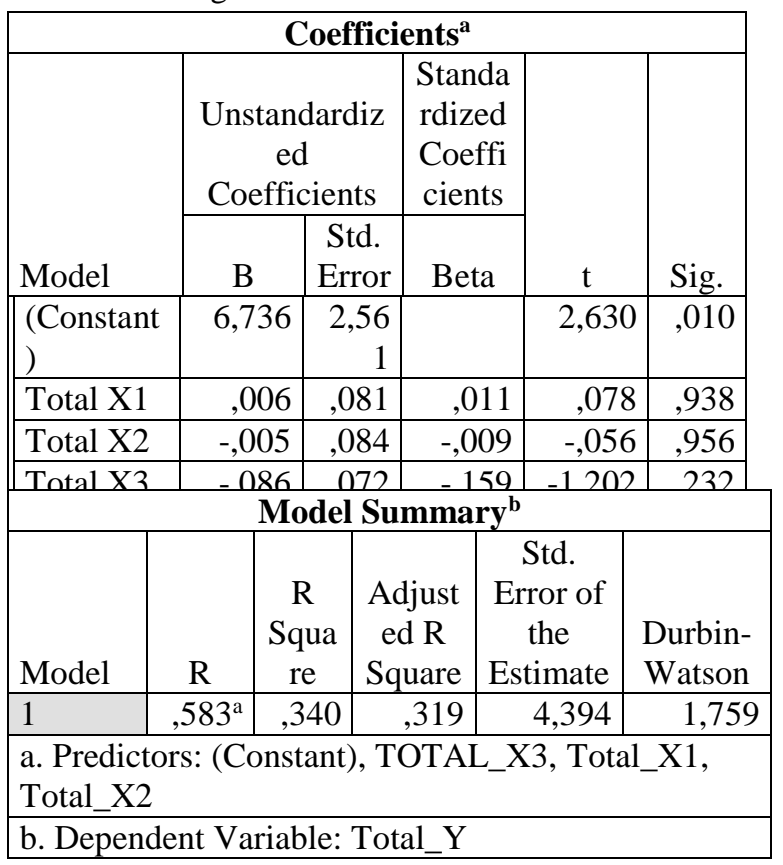

Table diatas menunjukan bahwa nilai signifikan (Asymp. Sig. 2-tailed) sebesar 0,182. Karena nilai signifikansi > dari 0,1 sehingga nilai residual terdistribusi normal.

\section{Uji Multikolonieritas}

Berdasarkan tabel diatas terlihat bahwa nilai tolerance variabel staretegi promosi yaitu 0,492 , variabel citra merk yaitu 0,441 dan variabel kualitas produk yaitu 0,591 yang artinya masing-masing variable memiliki nilai tolerance $>0,100$. Sedangkan nilai VIF untuk variabel

startegi promosi yaitu 2,031, variabel citra merk yaitu 2,267 dan variabel kualitas produk 1,691 yang artinya masing-masing

Vol. 12, No. 1, Januari 2021, Halaman 26-37 variabel memiliki nilai $\mathrm{VIF}<10$, maka dapat disimpulkan pada model regresi yang terbentuk tidak terjadi gejala multikoliniearitas.

\section{Uji Heteroskedastisitas}

Dari tabel diatas dapat dilihat nilai thitung untuk variabel strategi promosi $\left(\mathrm{X}_{1}\right)$ sebesar 0,078 variabel citra merk $\left(\mathrm{X}_{2}\right)$ sebesar -0,056 dan kualitas produk $\left(\mathrm{X}_{3}\right)$ sebesar $-1,202<\mathrm{t}_{\text {table }}$ (1.291). Sedangkan nilai signifikan untuk variabel startegi promosi $\left(\mathrm{X}_{1}\right)$ sebesar 0,938 , variabel citra merk $\left(\mathrm{X}_{2}\right)$ sebesar 0,956 dan variabel kualitas produk $\left(\mathrm{X}_{3}\right)$ sebesar 0,232 maka dapat disimpulkan bahwa masing-masing variabel $X_{1}, X_{2}$ dan $X_{3}$ memiliki nilai signifikan > 0.1 maka, dapat disimpulkan model regresi tidak terjadi gejala heteroskedastisitas.

\section{B. Uji Keandalan Model \\ 1. Uji Koefeisien Determinasi $\left(\mathbf{R}^{2}\right)$}

Dari tabel diatasdapat dilihat bahwa nilai R Square sebesar 0,340 yang artinya variabel strategi promosi, citra merk dan kualitas produk memiliki kontribusi pengaruh terhadap keputusan pembelian sebesar $34 \%$ dan sisanya $66 \%$ dijelaskan oleh variabel lain di luar variabel penelitian.

\begin{tabular}{|l|r|r|}
\hline \multirow{2}{*}{ Model } & \multicolumn{2}{|c|}{ Collinearity Statistics } \\
\cline { 2 - 3 } & Tolerance & \multicolumn{1}{c|}{ VIF } \\
\hline (Constant) & & \\
\hline Strategi Promosi & 0,492 & 2,031 \\
\hline Citra Merk & 0,441 & 2,267 \\
\hline Kualitas Produk & 0,591 & 1,691 \\
\hline
\end{tabular}

\section{Uji Hipotesis Regresi Linier Berganda}

a. Uji Hipotesis Secara Parsial (Uji T) 
Persamaan regresi linier disusun sebagai berikut:

$\mathrm{Y}=10,476+0,358$ Strategi Promosi + 0,144 Citra Merk + 0,240 Kualitas

Produk $+\mathrm{e}$

a. Koefisien regresi variabel startegi promosi sebesar 0,358

Koefisien regresi variabel strategi promosi adalah 0,358. Pengujian hipotesis secara parsial menggunakan uji t diperoleh nilai $t_{\text {hitung }}$ $2,687>t_{\text {table }}$ (1.290) dengan sig. sebesar ,009 < 0,1, sehingga $\mathrm{H}_{\mathrm{a}}$ dierima dan $\mathrm{H}_{\mathrm{o}}$ ditolak. Dapat disimpulkan bahwa strategi promosi mempengaruhi keputusan pembelian pada GR. Mart Banjarmangu. Dengan demikian maka hipotesis pertama dinyatakan terbukti.

Hipotesis $1(\mathrm{H} 1)$ ada pengaruh positif dan signifikan antara strategi promosi terhadap keputusan pembelian.

b. Koefisien regresi variabel citra merk sebesar 0,144

Koefisien regresi variabel citra merk adalah bertanda positif sebesar 0,144 . Pengujian hipotesis secara parsial menggunakan uji $\mathrm{t}$ diperoleh nilai thitung $1,032<\mathrm{t}_{\text {table }}(1.290)$ dengan sig. sebesar 0,305 >0,1, sehingga $\mathrm{H}_{\mathrm{a}}$ ditolak dan $\mathrm{H}_{\mathrm{o}}$ diterima. Maka dapat disimpulkan bahwa citra merk tidak bepengaruh terhadap keputusan pembelian pada GR. Mart Banjarmangu. Dengan demikian maka hipotesis kedua dinyatakan tidak terbukti.

Hipotesis $2(\mathrm{H} 2)$ tidak ada pengaruh antara citra merk terhadap keputusan pembelian.

c. Koefisien regresi variabel kualitas produk sebesar 0,240

\begin{tabular}{|c|c|c|c|c|c|c|}
\hline \multicolumn{7}{|c|}{ Coefficients $^{\mathrm{a}}$} \\
\hline \multirow{2}{*}{\multicolumn{2}{|c|}{ Model }} & \multicolumn{2}{|c|}{$\begin{array}{l}\text { Unstandardi } \\
\text { zed } \\
\text { Coefficients }\end{array}$} & $\begin{array}{c}\text { Stan } \\
\text { dardi } \\
\text { zed } \\
\text { Coef } \\
\text { ficie } \\
\text { nts }\end{array}$ & \multirow[b]{2}{*}{ t } & \multirow[b]{2}{*}{ Sig. } \\
\hline & & B & $\begin{array}{l}\text { Std. } \\
\text { Error }\end{array}$ & Beta & & \\
\hline 1 & $\begin{array}{l}\text { (Consta } \\
\text { nt) }\end{array}$ & $\begin{array}{r}10,4 \\
76\end{array}$ & $\begin{array}{r}4,23 \\
4\end{array}$ & & 2,474 & 015 \\
\hline & Total X1 & ,358 &, 133 &, 321 & 2,687 & ,009 \\
\hline & Total X2 &, 144 &, 139 &, 130 & 1,032 &, 305 \\
\hline & Total X3 & 240 &, 118 & ,221 & 2,030 & 045 \\
\hline
\end{tabular}

Koefisien regresi variabel citra merk adalah bertanda positif sebesar 0,240. Pengujian hipotesis secara parsial menggunakan uji $\mathrm{t}$ diperoleh nilai thitung 2,030 $>\mathrm{t}_{\text {table }}$ (1.290) dengan sig. sebesar ,045 $<0,1$, sehingga $\mathrm{H}_{\mathrm{a}}$ dierima dan $\mathrm{H}_{\mathrm{o}}$ ditolak. Dapat

\begin{tabular}{|l|c|r|r|r|r|}
\hline \multicolumn{7}{|c|}{ ANOVA $^{\mathbf{a}}$} \\
\hline & & & & & \\
\hline Model & $\begin{array}{c}\text { Sum of } \\
\text { Squares }\end{array}$ & df & \multicolumn{1}{c|}{$\begin{array}{c}\text { Mean } \\
\text { Square }\end{array}$} & F & Sig. \\
\hline $\begin{array}{l}\text { Regressi } \\
\text { on }\end{array}$ & 936,917 & 3 & 312,306 & 16,172 & $\begin{array}{r}, 00 \\
0\end{array}$ \\
\hline Residual & 1815,287 & 94 & 19,312 & & \\
\hline Total & 2752,204 & 97 & & & \\
\hline \begin{tabular}{l} 
a. Dependent Variable: Total_Y \\
\hline
\end{tabular} \\
b. Predictors: (Constant), TOTAL_X3, Total_X1, \\
Total_X2 \\
\hline
\end{tabular}

disimpulkan bahwa kualitas produk mempengaruhi keputusan pembelian pada GR. Mart Banjarmangu. Dengan demikian maka hipotesis pertama dinyatakan terbukti.

Hipotesis $3(\mathrm{H} 3)$ ada pengaruh positif dan signifikan antara kualitas produk terhadap keputusan pembelian.

\section{Uji Hipotesis Secara Simultan (Uji F)}


Uji Anova tersebut di atas diperoleh nilai F hitung 16,172 > f tabel sebesar 2,01 dengan sig. sebesar $0,000<0,1$ yang berarti ada pengaruh secara simlutan sehingga Ha diterima dan Ho ditolak. Dapat ditarik kesimpulan yaitu strategi promosi, citra merk dan kualitas produk secara bersama-sama berpengaruh positif dan signifikan terhadap Keputusan pembelian pada GR. Mart Banjarmangu.

Hipotesis 4 (H4) starategi promosi, citra merk dan kualitas produk bersama-sama memiliki pengaruh positif dan signifikan terhadap keputusan pembelian di GR. Mart Banjarmangu.

\section{PEMBAHASAN}

1. Pengaruh Strategi Promosi Terhadap Keputusan pembelian

Strategi promosi terhadap keputusan pembelian sangat erat kaitanya. Pada dasarnya tujuan akhir dari pemasaran itu tetap akan bermuara pada tercapainya kepuasan konsumen dan target penjualan yang terpenuhi. Penentuan strategi promosi yang baik akan mendorong seorang konsumen untuk melakukan suatu pembelian. Namun jika strategi promosi kurang baik atau jelek maka kemungkinan konsumen tidak akan melakukan keputusan pembelian terhadap produk tersebut (Keller, 2016).

Berdasarkan hasil analisis
penelitian sebelumnya yang
dilakukan oleh Aprianto (2016)
menyatakan bahwa terdapat
hubungan yang signifikan antara
strategi promosi dengan keputusan
pembelian di toko BNJ Elektronik di

Kota Lubuklinggau Sumatera Selatan.

Strategi promosi memiliki pengaruh terhadap keputusan pembelian, semakin tepat starategi promosi yang dilakukan oleh sebuah perusahaan maka akan meningkatkan keputusan pembelian yang dilakukan oleh konsumen.

2. Pengaruh Citra Merk Terhadap Keputusan pembelian

Citra merk merupakan identitas tersendiri terhadap suatu produk. Penetapan merk yang baik akan menimbulkan citra merk yang kuat dibenak konsumen. Karena merk yang sudah melekat di hati konsumen merupakan aset yang paling berharga bagi perusahaan. Dengan mempertahankan keunggulan citra merk yang dimiliki sebenarnya perusahaan menginginkan terdapat sikap konsumen yang selalu menyukai merk, menunjukan perilaku yang loyal terhadap merk tersebut sehingga menimbulkan sikap puas akan merk tersebut dan juga berkomitmen terhadap merk tersebut ( Park et al, 2012).

Penelitian terdahulu yang dilakukan oleh Sari, Mandey, dan Soegito (2014) menyatakan bahwa citra merk tidak terdapat pengaruh terhadap keputusan pembelian.

Citra merk tidak memiliki pengaruh terhadap keputusan pembelian, artinya bahwa jika citra merk pada sebuah perusahaan kurang baik maka tidak akan mempengaruhi konsumen untuk melakukan keputusan pembelian.

\section{Pengaruh Kualitas Produk Terhadap Keputusan pembelian}


Kualitas produk adalah suatu tindakan yang diberikan oleh perusahaan untuk memenangkan persaingan dipasar dengan sekumpulan perbedaan-perbedaan yang berarti pada produk atau jasa yang ditawarkan untuk membedakan produk perusahaan dengan produk pesaingnya.

Dengan mempertahankan kualitas produk maka seorang konsumen akan loyal untuk melakukan keputusan pembelian terhadap produk yang kita miliki (Monalisa, 2015).

Penelitian terdahulu yang dilakukan oleh Sugiono (2013) menyatakan bahwa kualitas produk berpengaruh terhadap keputusan pembelian.

Kualitas produk memiliki pengaruh terhadap keputusan pembelian, artinya bahwa semakin baik kualitas produk pada sebuah perusahaan akan meningkatkan keputusan pembelian oleh konsumen karena memang konsumen akan lebih terbarik untuk membeli produk jika produk yang ditawarkan berkualitas.

4. Pengaruh Strategi Promosi, Citra Merk dan Kualitas Produk Terhadap Keputusan pembelian

Strategi promosi, citra merk, dan kualitas produk merupakan hal yang akan memberikan manfaat sangat besar bagi kelancaran proses kegiatan bisnis, salah satunya untuk mendorong keputusan pembelian terhadap suatu produk yang nantinya akan di pasarkan oleh perusahaan, strategi pemasaran dan promosi yang tepat akan membantu kita untuk mencapai target penjualan, dan citra merk yang baik akan mendorong seorang konsumen untuk melakukan keputusan pembelian (Keller, 2010).

Penelitian yang dilakukan oleh oleh Prawira (2014) dapat disimpulkan bahwa ada hubungan yang signifikan antara strategi promosi, citra merk, dan kualitas produk dengan keputusan pembelian smartphone samsung di kota Denpasar.

Strategi promosi, citra merk dan kualitas produk berpengaruh terhadap keputusan pembelian, Apabila sebuah perusahan memberikan kualitas produk yang baik dan melakukan strategi promosi yang tepat secara tidak langsung akan memunculkan citra merk yang baik kepada masyarakat, dan sering memberikan promosi maka kemungkinan besar seorang konsumen akan melakukan keputusan pembelian.

\section{KESIMPULAN}

Kesimpulan dari hasil penelitian ini antara lain sebagai berikut:

1. Strategi promosi berpengaruh positif dan signifikan terhadap keputusan pembelian.

2. Citra merek tidak berpengaruh terhadap keputusan pembelian.

3. Kualitas produk berpengaruh positif dan signifikan terhadap keputusan pembelian

4. Strategi promosi, citra merek dan kualitas produk berpengaruh positif dan signifikan terhadap keputusan pembelian.

\section{SARAN}

1. Saran yang dapat peneliti sampaikan untuk Guyub Rukun Mart Banjarmangu. 
Untuk menciptakan keputusan pembelian yang tinggi hal yang pertama harus dilakukan oleh Guyub Rukun Mart Banjarmangu adalah dengan memberikan produk-produk dan pelayanan yang berkualitas dan melakukan strategi promosi yang baik dan tepat maka secara tidak langsung akan membuat citra merek pada Guyub Rukun Mart Banjarmangu baik sehingga akan menimbulkan keputusan pembelian yang tinggi dari konsumen.

2. Peneliti Lanjutan

Penelitian lanjutan hendaknya dilakukan dengan menggali lebih banyak variabel sebagai prediktor baik melalui kajian teoretis maupun melalui penelitian sebelumnya karena penelitian ini hanya menggunakan variabel strategi promosi, citra merek dan kualitas produk.

DAFTAR PUSTAKA

Alfajri. 2016. Hubungan Strategi Promosi

Dengan Keputusan Pembelian

Gadget di Toko Suryaphone

Samarinda.

Ejournal.psikologi.fisip-

unmul.ac.id, vol 6, No. 3 .

Amir, Muhammad. 2019. Pengaruh Strategi Promosi Terhadap Keputusan Pembelian Pada PT. Sumber Alfaria Trijaya Makasar. Movere Journal, Vol. 1, No 1.

Apriato. 2016. Pengaruh Promosi Dan Pelayanan Terhadap Kepuasan Pelanggan Pada Toko BNJ Elektronik Kota Lubuklinggau. Bulletin bisnis dan manajemen, vol.2, no.1.
Aziz. Nazarudin. 2019. Pengaruh trategi Promosi Terhadap Keputusan Pembelian di KFC Cabang Khatib Sulaiman Padang. Jurnal Manajemen, Vol.1 No.3.

Chan, Arians. Pengaruh Ekuitas Merek Terhadap Proses Keputusan Pembelian Konsumen: Studi Kasus Bank Muamalat Indonesia Cabang Bandung. Jurnal Administrasi Bisnis, Vol 6, No. 1.

Fernando. Fajar. 2018. Pengaruh Kualitas Produk, Harga, Promosi, dan Distribusi Terhadap Keputusan Pembelian Produk Sanitary Ware Toto di Kota Denpasar. Jurnal Manajemen, Vol.7 No.1.

Ghozali,imam. 2013. Aplikasi analisis multivariate dengan program IBM SPSS 21 update PLS Regresi: Badan Penerbit Universitas Diponegoro.

Kamaludin, Ahmad. 2017. Pengaruh Strategi Promosi dan Kualitas Produk Terhadap keputusan Pembelian di PT. Sarana Panca Karya. Jurnal ilmiah Indonesia, Vol.2 No. 3.

Keller. 2016. Management Pemasaran Edisi 12 Jilid 1 dan 2.

Jakarta: Pt.Indeks.

Prawira. Bayu. 2014. Pengaruh Kualitas Produk dan Citra Merk Terhadap Minat Beli Produk Smartphone Samsung di Kota Denpasar. Jurnal Manajemen, Vol.1 No.2. 
Priyanti. 2017. Minat Beli Konsumen toko Sepatu Bata di Pasar Raya Padang. Jurnal pundi, Vol.1 No.2.

Rawung. Rayen. 2015. Analisis Kualitas Produk, Citra Merk, dan Harga Terhadap Keputusan Pembelian Sepeda Motor Suzuki pada Pt, Sinar Galesong Pratama Manado. Jurnal Emba, Vol.3 No.3.

Sugiyono. 2011. Metode Penelitian Kuantitatif, Kuaitatif dan $R \& D$. Bandung: Afabeta

Sugiyono. 2013. Pengaruh Strategi Promosi, Citra Merk, dan Kualitas Produk Terhadap Keputusan Pembelian di Cincau Station Surabaya. Jurnal manajemen pemasaran, Vol.1 No.2.

Suliyanto. 2010. Studi Kelayakan Bisnis Pendekatan Praktis. Andi Offset.

Yogyakarta.

Suliyanto. 2011 "Ekonometrika Terapan: Teori Dan Aplikasi Dengan SPSS". Edisi 1. Yogyakarta:ANDI Yogyakarta

Wangko, Christine. 2013. Pengaruh Strategi Bauran Pemasaran Terhadap Keputusan Pembelian Mobil Phanter Pada PT. Astra Internasional. Jurnal EMBA, Vol 1, No 3 ..

Whenas, Jackson.2013. Kualitas Produk, Harga, Promosi, dan Pelayanan Pengaruhnya Terhadap Keputusan Pembelian Spring Bed Comforta. Jurnal EMBA, Vol. 1, No. 4.
Wijaya. 2013. Promosi, citra Merk, dan Saluran Distribusi Pengaruhnya Terhadap Keputusan Pembelian Jasa Terminix di Kota Manado. Jurnal riset ekonomi, Vol.1 No.4.

Mongi. Lidya. 2014. Kualitas Produk, Strategi Promosi dan Harga Pengaruhnya Terhadap Keputusan Pembelian Kartu Telkomsel di Kota Manado. Jurnal Emba, Vol.1 No.4. 